\title{
Obtaining tetraploid plants of ruzigrass (Brachiaria ruziziensis)
}

\author{
Ana Luiza de Oliveira Timbó ${ }^{1}$, Patrícia Nirlane da Costa Souza1, Roselaine Cristina Pereira1, \\ Juliane Dornellas Nunes², José Eduardo Brasil Pereira Pinto ${ }^{3}$, Fausto de Souza Sobrinho², \\ Lisete Chamma Davide ${ }^{1}$
}

\footnotetext{
${ }^{1}$ Departamento de Biologia, Universidade Federal de Lavras, Lavras, MG, Brasil.

${ }^{2}$ Embrapa Gado de Leite, Juiz de Fora, MG, Brasil.

${ }^{3}$ Departamento de Agricultura, Universidade Federal de Lavras, Lavras, MG, Brasil.
}

\begin{abstract}
The objective of the present work was to induce chromosome doubling in genotypes of Brachiaria ruziziensis with potential for production of good-quality biomass and tolerance/resistance to stress caused by aluminum and spittlebugs. Germinated seeds of B. ruziziensis were immersed in $0.1 \%$ colchicine solution for 2 or 3 hours. Ploidy level was determined by flow cytometry and confirmed by chromosome count. Fertility of the tetraploid plants was assessed through evaluation of pollen viability by staining. There was no statistical difference with regard to seedling survival and number of duplicate seedlings between the treatments. Survival rate was $8 \%$, of which $11.45 \%$ were tetraploid genotypes. The mean viability of pollen grains from the evaluated tetraploid plants ranged from 51.75 to $55.50 \%$. So, the tetraploids plants obtained from genotypes of a bred population of ruzigrass produce fertile pollen, in percentages that render crosses viable in genetic breeding programs.
\end{abstract}

Key Words: DNA content, forage plant breeding, number of chromosomes, polyploidy induction, pollen viability

\section{Introduction}

In Brazil, it is estimated that an area of 172 million hectares of pasture is used to feed a herd of approximately 170 million cattle (IBGE, 2006). The Brachiaria species most grown in Brazil are $B$. decumbens, B. brizantha, $B$. humidicola and $B$. ruziziensis; basically, only two cultivars of two species (cv. Basilisk of B. decumbens and Marandu of $B$. brizantha) are planted (Simioni and Valle, 2009). Although $B$. ruziziensis is not the most grown species, it is recognized within the genus as providing higher quality forage, a feature of interest in interspecific crosses to exploit the genetic variability of the genus (Swenne et al., 1981; Pinheiro et al., 2000; Ishigaki et al., 2009; Simioni and Valle, 2009). The advantage of B. ruziziensis lies on the fact that it is a sexual and diploid species, while the remaining are predominantly tetraploid and facultative apomictic plants (Valle and Savidan, 1996). This way, crosses involving this species, as well as the generation of variability for selection of superior materials, are possible (Souza Sobrinho et al., 2009; 2010).

To this effect, the induction of polyploidy constitutes an alternative both for obtaining adapted cultivars and for making interspecific crosses viable with tetraploid cultivars of Brachiaria, as the duplicate plants of B. ruziziensis maintain the sexual reproduction mode (Simioni and Valle, 2009). In addition, artificial polyploidization may be used to increase plant size, restore fertility in intra- and interspecific hybrids, or allow gene introgression between individuals with different levels of ploidy (Swenne et al., 1981; Pinheiro et al., 2000; Ishigaki et al., 2009; Simioni and Valle, 2009).

In Brachiaria, artificial tetraploid plants were first obtained for genotypes of B. ruziziensis (Swenne et al., 1981), and later for diploid accessions of $B$. decumbens (Simioni and Valle, 2009), B. brizantha (Pinheiro et al., 2000) and B. ruziziensis (Ishigaki et al., 2009). In all these studies, colchicine was used as a polyploidizing agent, with variation in the concentrations used, time of exposure, type of explant, and execution manner, i.e., in vivo or in vitro.

Although some artificially tetraploidized B. ruziziensis plants are used for genetic breeding in the genus, in all events duplication occurred beginning with random genotypes, i.e., without previous selection for forage characteristics. In general, the plants generated did not exhibit favorable characteristics with regard to Brazilian environmental conditions. In this sense, the use of previously selected Brazilian genotypes of B. ruziziensis would probably increase the probability of generating tetraploid plants with favorable forage characteristics, which could lead to superior interspecific hybrids. 
The objective of this study was to induce polyploidy in genotypes of B. ruziziensis with potential for goodquality biomass and tolerance/resistance to stress caused by aluminum and spittlebugs.

\section{Material and Methods}

Seeds from a B. ruziziensis population originating from the second cycle of intrapopulation recurrent selection at Embrapa Gado de Leite - MG (Embrapa Dairy Cattle Breeding Program - MG) were used.

The seeds were initially subjected to treatment with concentrated sulfuric acid for 15 minutes to promote breaking of dormancy, then rinsed three times with distilled water.

The seeds were placed for germination in gerbox containing filter paper, moistened with distilled water, and maintained in a B.O.D $\left(20-35^{\circ} \mathrm{C}\right)$ incubator with an eight-hour photoperiod. After three days, the seedlings presenting root growth of approximately $0.5 \mathrm{~cm}$ length were immersed in $10 \mathrm{~mL}$ of $0.1 \%$ colchicine solution for 2 or 3 hours, according to Swenne et al. (1981) with modifications made in the times of exposure to colchicine, which were defined in a pre-test and based on the work of Ishigaki et al. (2009). Four replications per treatment and 150 seedlings/replication were evaluated, according to Swenne et al. (1981), with modifications.

After polyploidy induction treatments, the seedlings were transferred to tubettes containing dirt:sand:manure (1:1:1). The plug containers were kept in a greenhouse with a mist spray system to control air humidity and irrigation.

Five months after installation of the experiment, the ploidy level of the surviving plants was determined, including diploid plants (control), using the flow cytometry technique. Analyses were performed separately for young leaves of each tiller. Three samples per tiller were evaluated, and the DNA content and ploidy level of each tiller plant were estimated.

For determination of DNA content and ploidy level, 20 to $30 \mathrm{mg}$ of young-leaf tissue were used for each sample, along with the same amount of leaf mass of Raphanus sativus cv. Saxa (reference standard with $1.11 \mathrm{pg}$ of DNA). Subsequently, the samples were ground in a Petri dish containing $1 \mathrm{~mL}$ of nuclear extraction buffer $\mathrm{MgSO}_{4}$ (Dolezel et al., 1989; Dolezel and Bartos, 2005). The nuclear suspension was filtered through $50-\mu$ m nylon mesh and stained with solution composed of $20 \mu \mathrm{L}$ of $1 \mathrm{mg} \cdot \mathrm{mL}^{-1}$ propidium iodide and $5 \mu \mathrm{L}$ of RNase.

The samples were stored in a refrigerator, in the dark, and analyzed within one hour of preparation. For each sample, at least 10,000 nuclei were analyzed with regard to emission of fluorescence using a logarithmic scale. The analysis was performed in a FacsCalibur flow cytometer (BD Biosciences, San Jose, CA, USA). Histograms were obtained with the program Cell Quest (Becton, Dickinson and Company, San Jose, CA, USA), and analyses of the histograms were accomplished with the program WinMDI 2.8 (Trotter, 2000).

The adopted experimental design was completely randomized, with two treatments (exposure time of $2 \mathrm{~h}$ or $3 \mathrm{~h}$ ), and the variables survival percentage in each treatment and ploidy level of each one of the obtained plants were observed. Data regarding the number of surviving seedlings and ploidy level of the seedlings were transformed into $\sqrt{x}+0.5$ (Gomes, 2009), and the mean values were compared by the Scott-Knott (1974) test at 5\% probability. Analysis of variance of the test in the completely randomized design followed the recommendations of Ramalho et al. (2005) using the Sisvar program (Ferreira, 2000).

To confirm the results obtained by flow cytometry, the number of chromosomes of the diploid (control) and tetraploid plants was evaluated. To obtain metaphase chromosomes, the tips of the collected roots were subjected to pretreatment with $25 \mathrm{mg} . \mathrm{L}^{-1}$ cycloheximide and $300 \mathrm{mg} . \mathrm{L}^{-1}$ hydroxyquinoline (1:1) solution for $2: 45$ hours, in a refrigerator, as described by Techio et al. (2002), with modifications. After pretreatment, the roots were washed in distilled water for 5 minutes (3x), air-dried, fixed in Carnoy's solution (ethanol:acetic acid, 3:1) for at least 24 hours, and stored in a freezer until the time of use. For slide preparation, the roots were subjected to enzymatic maceration in solution containing pectinase (100 U) and cellulase (50 U) for 6 hours. The slides were prepared by squashing, followed by staining with $5 \%$ Giemsa for 10 minutes.

Twenty metaphases of each analyzed genotype were evaluated using a Leica-DMLS microscope with a coupled Nikon DS-Fil camera for image capture.

Pollen fertility was estimated in fresh dehiscent anthers of three tetraploid plants of B. ruziziensis (genotypes 14, $39,45)$, with a diploid plant used as control. Pollen grain viability was evaluated by staining with $2 \%$ acetocarmine. The pollen grains showing reddish staining were considered viable, and the unstained grains were regarded as unviable. A completely randomized design with four replications was used for this analysis, with 200 pollen grains evaluated per replication. Data were subjected to analysis of variance using the statistical program Sisvar ${ }^{\circledR}$ (Ferreira, 2000), and the mean values were compared by the Scott-Knott test at $5 \%$ probability level. 


\section{Results and Discussion}

There were no statistical differences between the mean survival values of the plants in the different times of exposure to $0.1 \%$ colchicine (Table 1 ).

Overall, 96 plants survived the treatments with colchicine, corresponding to $8 \%$ of the evaluated plants. For the treatment with 2-hour exposure time, a 9.3\% survival rate was observed, and $6.6 \%$ for 3-hour exposure time. Ishigaki et al. (2009) achieved a survival rate of $16 \%$ in an in vitro treatment of germinated plants in culture medium containing $0.1 \%$ colchicine for 3 hours. The greater survival rate found by this author was probably because the seedlings remained in contact with the nutritional culture medium during the treatment, thus reducing the stress caused by colchicine.

Flow cytometry was used to estimate the DNA content of the 96 surviving plants as well as to verify the occurrence of chromosome duplication (Figure 1A-D). The diploid control plant and the tetraploid plants respectively showed, on average, 1.48 and $2.92 \mathrm{pg} / 2 \mathrm{C}$ of DNA (Figures $1 \mathrm{~B}$ and 1C), confirming chromosome duplication. These tetraploidized plants did not show a diploid peak, which indicates a reduced possibility of mixoploid occurrence (Figure 1D). Ishigaki et al. (2009) also found values close to these for the DNA content of B. ruziziensis, with $1.41 \mathrm{pg} / 2 \mathrm{C}$ for the diploid plants and $2.77 \mathrm{pg} / 2 \mathrm{C}$ for the tetraploidized ones.

In addition to diploids and tetraploids, mixoploid plants (Mix) were also obtained, in the histograms of which diploid and tetraploid peaks were present (Figure 1D). Mixoploid plants with tillers showing different levels of ploidy $(2 \mathrm{x}, 4 \mathrm{x}$ or Mix) were classified as $2 \mathrm{x}+\mathrm{Mix}, 2 \mathrm{x}+4 \mathrm{x}$, and Mix $+4 \mathrm{x}$ (Table1).

Plants containing $4 \mathrm{x}$ tillers in the clump $(2 \mathrm{x} / 4 \mathrm{x}$ and mixoploid/4x) were carefully isolated, thus generating three more tetraploid plants. Therefore, considering the eight $4 \mathrm{x}$ plants as well as the three derived from tillers, eleven polyploidized plants were obtained (Table 1). This result shows the importance of analyzing and marking each tiller of a plant subjected to duplication.

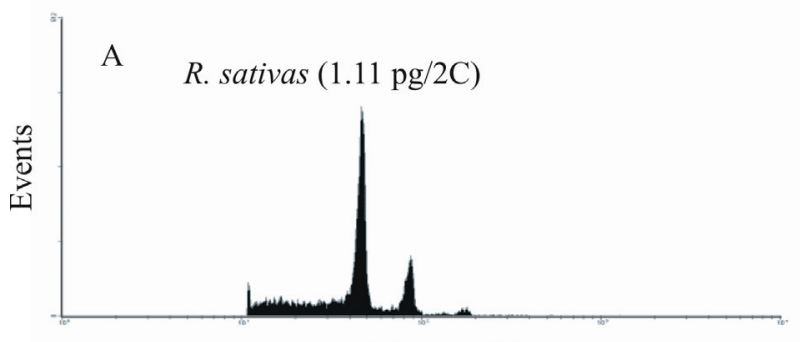

Propidium Iodide

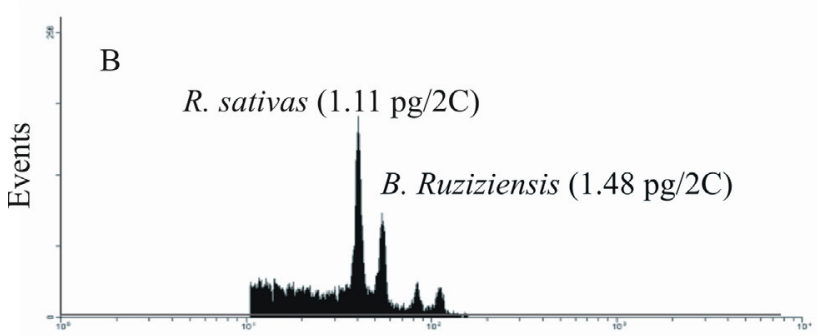

Propidium Iodide

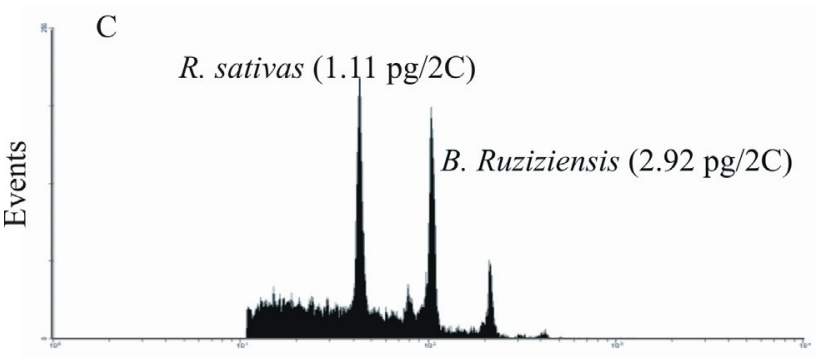

Propidium Iodide

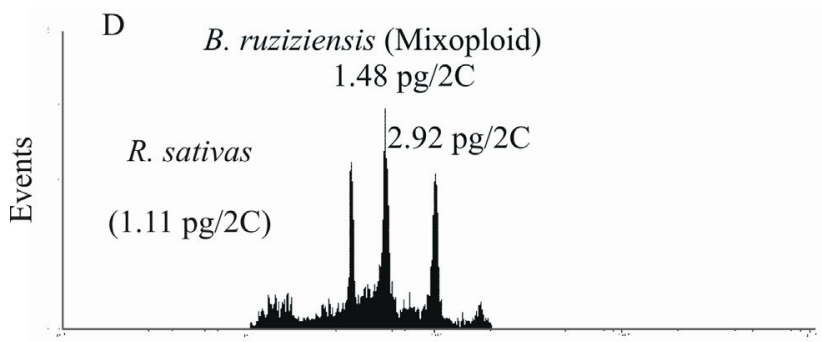

Propidium Iodide

A) Raphanus sativus (reference standard); B) diploid plant; C) tetraploidized plant; and D) mixoploid plant.

Figure 1 - Histograms representing flow cytometry for quantification of the DNA content of isolated nuclei from Brachiaria ruziziensis leaves.

Table 1 - Survival (\%) and ploidy level of B. ruziziensis seedlings subjected to treatments with colchicine solution

\begin{tabular}{|c|c|c|c|c|c|c|c|c|c|}
\hline \multirow{2}{*}{ Time hours (h) } & \multirow{2}{*}{ Conc. $(\%)$} & \multirow{2}{*}{ No. of treated seedlings } & \multirow{2}{*}{ No. of surviving seedlings ${ }^{1}$} & \multicolumn{6}{|c|}{ Ploidy level $^{2}$} \\
\hline & & & & $2 \mathrm{x}$ & $2 x+$ Mix & $2 x+4 x^{3}$ & $\operatorname{Mix}+4 \mathrm{x}$ & $\mathrm{Mix}^{3}$ & $4 \mathrm{x}$ \\
\hline 2 & 0.1 & 600 & $56(9.3 \%)$ & 43 & 2 & 1 & 1 & 5 & 4 \\
\hline 3 & 0.1 & 600 & $40(6.6 \%)$ & 27 & 5 & 1 & 0 & 3 & 4 \\
\hline Total & & 1200 & $96(8 \%)$ & 70 & 7 & 2 & 1 & 8 & 8 \\
\hline
\end{tabular}

Conc - colchicine concentration; Mix - mixoploidy.

${ }^{1}$ The treatments do not differ statistically at $5 \%$ probability by the Scott-Knott test.

${ }^{2}$ Ploidy level estimated by flow cytometry.

${ }^{3} 2 \mathrm{x} / 4 \mathrm{x}=$ genotype with $4 \mathrm{x}$ and $2 \mathrm{x}$ tillers. 
Swenne et al. (1981) achieved chromosome duplication of 35 B. ruziziensis plants, corresponding to $18.51 \%$ of 189 surviving plants. Polyploidization was induced in 600 seeds germinated in vivo, treated with five different concentrations of colchicine solution $(0.05,0.1,0.2,0.5$ and $1 \%)$ and four different treatment times $(1,2,4$ and $8 \mathrm{~h})$. In this study, the treatments with best results were: 1 hour $(0.1,0.2$ and $1 \%$ colchicine solution), 2 hours $(0.2$ and $0.5 \%$ colchicine solution), 4 hours $(0.05 \%$ colchicine solution) and 8 hours ( $0.2 \%$ colchicine solution). Ishigaki et al. (2009) induced chromosome duplication in seeds germinated in vitro and treated in culture medium supplemented with $0.1 \%$ colchicine for 3 hours, obtaining a higher survival rate $(16 \%)$ and duplication percentage (31.3\%) than those presented in this study (6.6 and $12.5 \%$ ).

The plants classified by flow cytometry as tetraploids presented 36 chromosomes, while the diploid control plants presented 18 chromosomes (Figure 2). These results confirm duplication of the number of chromosomes of the $B$. ruziziensis plants that underwent treatment with colchicine. The mean percentage of pollen grain viability ranged from 51.75 to $55.50 \%$ for the three evaluated tetraploid plants (Table 2); for the diploid B. ruziziensis plant, used as control, this value was $76.25 \%$. The mean percentage of pollen grain viability observed in the analyzed plants was $53.67 \%$, thus greater than the $38.62 \%$ obtained by Risso-Pascotto et al. (2005b) for accessions of B. ruziziensis tetraploids. It is important to note that pollen viability tests based on staining are disputed, due to overestimation of the pollen viability. However, in virtue of being practical and fast, they can rapidly generate additional information that may orientate breeders in their choice of genitors, in works involving controlled pollinations. Acetocarmine and propionic carmine are

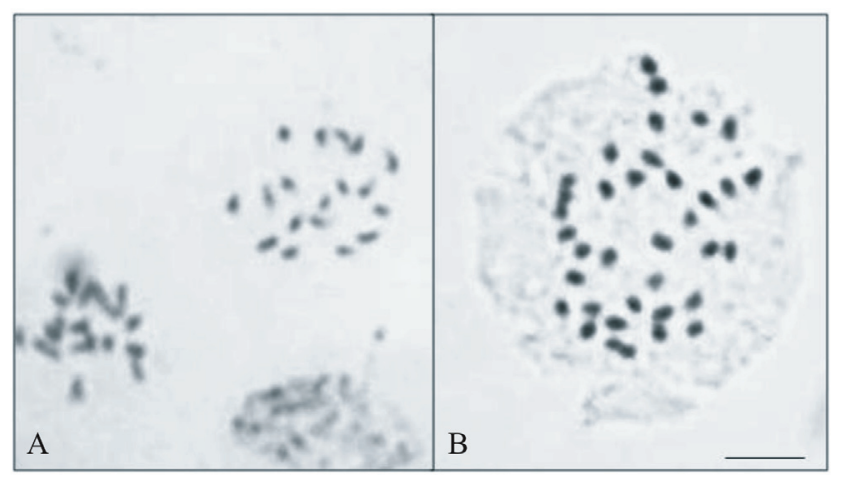

$\operatorname{Bar}=15 \mu \mathrm{m}$.

Figure 2 - Chromosome number of diploid $(2 n=2 x=18)(A)$ and tetraploid plants $(2 \mathrm{n}=4 \mathrm{x}=36)(\mathrm{B})$ of $B$. ruziziensis subjected to artificial polyploidization.
Table 2 - Pollen viability (\%) of artificially duplicated $B$. ruziziensis plants

\begin{tabular}{lc}
\hline Genotype & Mean value of pollen viability (\%) \\
\hline 14 & $51.75 \mathrm{a}$ \\
39 & $53.75 \mathrm{a}$ \\
45 & $55.50 \mathrm{a}$ \\
$2 \mathrm{x}$ (control) & $76.25 \mathrm{~b}$ \\
\hline
\end{tabular}

Mean values in the column followed by the same letter do not differ statistically by Scott-Knott's test at $5 \%$ probability.

the most used dyes to determine pollen viability, also in routine analyses (Zanotto et al., 2009). In another study using two hybrids between $B$. ruziziensis and $B$. brizantha, these same authors observed less than $35 \%$ of viable pollen grains, as well as meiotic abnormalities such as irregular chromosome segregation, chromosome adherence and abnormal cytokinesis, which probably affected the viability of the pollen (Risso-Pascotto et al., 2005a). Furthermore, Simioni and Valle (2009) observed mean pollen viability of $63.16 \%$ for three artificially tetraploidized accessions of B. decumbens.

The genotypes obtained in this study will be useful for genetic breeding of the genus, which uses tetraploidized B. ruziziensis as a bridge for generation of variability in the apomictic species $B$. brizantha and $B$. decumbens. $B$. ruziziensis provides palatable forage of high nutritional quality. It requires fertile, well-drained soils, and is highly susceptible to the most important insect pest in pastures - the spittlebug (Keller-Grein et al., 1996). In our work, chromosome doubling was carried out in genotypes obtained from a bred population, presenting productivity similar to that of commercial cultivars of B. ruziziensis available in Brazil as well as tolerance/resistance to stress caused by aluminum and spittlebugs (Souza Sobrinho, personal communication).

In addition, this is the first report of attainment of tetraploidized genotypes in Brachiaria ruziziensis on the American continent. Furthermore, the pollen viability indexes of these genotypes have been recently confirmed by seed production after controlled pollination (Souza Sobrinho, personal communication). This increases the chances of obtaining fertile interspecific hybrids, and may allow for increasing the expression of characteristics of interest for foraging in B. ruziziensis.

\section{Conclusions}

Artificially tetraploidized B. ruziziensis plants obtained from genotypes of a bred population produce fertile pollen, in percentages that render crosses viable in genetic breeding programs. 


\section{Acknowledgments}

The authors thank Dr. Ana Luíza Azevedo (Embrapa Gado de Leite) for collaboration in flow cytometry analyses and to FAPEMIG (Fundação de Amparo à Pesquisa do Estado de Minas Gerais) and CNPq (Conselho Nacional de Desenvolvimento Científico e Tecnológico) for providing financial support.

\section{References}

Dolezel, J. and Bartos, J. 2005. Plant DNA flow cytometry and estimation of nuclear genome size. Annals of Botany 95:99-110.

Dolezel, J.; Binarová, P. and Lucretti, S. 1989. Analysis of nuclear DNA content in plant cells by flow cytometry. Biologia Plantarum 32:113-120.

Ferreira, D. F. 2000. Análise estatística por meio do SISVAR para Windows versão 4.0. p.255-258. In: Anais da 45a Reunião Anual da Região Brasileira da Sociedade Internacional de Biometria. UFSCar, São Carlos, SP, Brasil.

Gomes, F. P. 2009. Curso de estatística experimental. FEALQ, Piracicaba.

IBGE - Instituto Brasileiro de Geografia e Estatística. 2006. Censo agropecuário 2006: resultados preliminares. Available at: $<\mathrm{http}: / /$ www.ibge.gov.br/home/presidencia/noticias/noticia_visualiza.php? id_noticia=1064id_pagina=1>. Accessed on: June 18, 2010.

Ishigaki, G.; Gondo, T.; Suenaga, K. and Akashi, R. 2009. Induction of tetraploid ruzigrass (Brachiaria ruziziensis) plants by colchicine treatment of in vitro multiple-shoot clumps and seedlings. Japanese Society of Grassland Science 5:164-170.

Keller-Grein, G.; Maass, B. L. and Hanson, J. 1996. Natural variation in Brachiaria and existing germoplasma collections. p.17-42. In: Brachiaria: biology, agronomy, and improvement. Miles, J. W.; Maass, B. L.; and Valle, C. B., eds. CIAT/Embrapa, Colombia.

Pinheiro, A. A; Pozzobon, M.T.; Valle, C. B.; Penteado, M. I. O. and Carneiro, V. T. C. 2000. Duplication of the chromosome number of diploid Brachiaria brizantha plants using colchicine. Plant Cell Reports 19:274-278.
Ramalho, M. A. P.; Ferreira, D. F. and Oliveira, A. C. 2005. Experimentação em genética e melhoramento de plantas. Editora UFLA, Lavras.

Risso-Pascotto, C.; Pagliarini, M. S. and Valle, C. B. 2005a. Meiotic behavior in interspecific hybrids between Brachiaria ruziziensis and Brachiaria brizantha (Poaceae). Euphytica 145:155-159.

Risso-Pascotto, C.; Pagliarini, M. S. and Valle, C. B. 2005b. Multiple spindles and cellularization during microsporogenesis in an artificially induced tetraploid accession of Brachiaria ruziziensis (Gramineae). Plant Cell Reports 23:522-527.

Scott, A. and Knott, M. 1974. Cluster-analysis method for grouping means in analysis of variance. Biometrics 30:507-512.

Simioni, C. and Valle, C. B. 2009. Chromosome duplication in Brachiaria (A. rich.) Stapf allows intraspecific crosses. Crop Breeding and Applied Biotechnology 9:328-334.

Souza Sobrinho, F.; Auad, A. M. and Lédo, F. J. S. 2010. Genetic variability in Brachiaria ruziziensis for resistance to spittlebugs. Crop Breeding and Applied Biotechnology 10:89-94.

Souza Sobrinho, F.; Ledo, F. J. S.; Kopp, M. M.; Pereira, A. V. and Souza, F. F. 2009. Melhoramento de gramíneas forrageiras na Embrapa Gado de Leite. p.98-111. In: Anais do 7o Simpósio de Forragicultura e Pastagens. UFLA, Lavras.

Swenne, A.; Louant, B. and Durjardin, M. 1981. Induction par la colchicine de formes autotetraploïdes chez Brachiaria ruziziensis Germain et Evrard (Graminée). Agronomie Tropicale 36:134-114.

Techio, V. H.; Davide, L. C; Pereira, A. V. and Bearzoti, E. 2002. Cytotaxonomy of some species and of interspecific hybrids of Pennisetum (Poaceae, Poales). Genetics and Molecular Biology 25:203-209.

Trotter, J. 2000. WinMDI ${ }^{\circ}$. Version 2.8. The Scripps Research Institute, La Jolla. Available at: $<$ http://facs.scripps.edu/software.html $>$. Accessed on: Mar. 15, 2010.

Valle, C. B. and Savidan, Y. H. 1996. Genetics, cytogenetics and reproductive biology of Brachiaria. p.147-163. In: Brachiaria: Biology, agronomy and improvement. Miles, J. W.; Maass, B. L.; do Valle, C. B., eds. CIAT, Colombia.

Zanotto, M.; Brammer, S. P.; Nascimento Jr., A. and Scagliusi, S. M. 2009. Viabilidade polínica como seleção assistida no programa de melhoramento genético de Triticale. Ciência e Agrotecnologia 33(Edição Especial):2078-2082. 